\title{
Cytotaxonomy of Sapindaceae with special reference to the tribe Paullinieae*
}

María S. Ferrucci

*Part of a thesis that will be presented by M.S.F. to the Facultad de Ciencias Exactas, Fisicas y Naturales of the Universidad Nacional de Córdoba, Argentina, in partial fulfillment of the requirements for the Doctoral degree. Instituto de Botánica del Nordeste (UNNE-CONICET), Casilla de Correo 209, (3400) Corrientes, Argentina. Fax: +54-0783-27131.

\section{INTRODUCTION}

Sapindaceae is a tropical and subtropical family comprising approximately 136 genera and about 2000 species. Radlkofer (1931-1934) recognized 14 tribes, of which Paullinieae is the only tribe characterized by a climbing habit, with the remaining tribes being shrubs or trees.

The most comprehensive studies on the karyology of Sapindaceae were done in the last decade (Ferrucci, 1989; Hemmer and Morawetz, 1990; Nogueira et al., 1995; Ferrucci and Solís Neffa, 1997; Solís Neffa and Ferrucci, 1997, 1998; Lombello and Forni-Martins, 1998), and chromosome numbers of 127 species have been reported and the complete karyotypes of 35 species are known, although only a few papers give information on interphase nucleus structure, chromosome condensing behavior, Giemsa Cbanding, NOR-banding and nucleolus counts (Eichhorn and Franquet, 1936; Guervin, 1961; Hemmer and Morawetz, 1990; Nogueira et al., 1995).

In the present study chromosome numbers are reported for 19 South American species of the tribe Paullinieae (Table I), with ten of them representing new records while previous reports are confirmed for other 9 species. These results are compared with a review of the karyology of the whole family, with special reference to the tribe Paullinieae in an attempt to improve the understanding of the evolution of the family.

The species studied, chromosome numbers, localities and collectors are listed in Table I. Voucher specimens have been deposited in the herbaria of the Instituto de Botánica del Nordeste (CTES), Argentina.

Cytological studies were carried out using root meristems of germinating seeds, except for Cardiospermum anomalum, where roots from adult plant were used. The roots were pre-treated for $3 \mathrm{~h}$ in $0.002 \mathrm{M} 8$-hydroxyquinoline at room temperature, fixed in ethanol and lactic acid (5:1) at $4^{\circ} \mathrm{C}$ and then stored in $70 \%$ ethanol. The roots were hydrolyzed in $1 \mathrm{~N} \mathrm{HCl}$ at $60^{\circ} \mathrm{C}$ for $8 \mathrm{~min}$ and stained with Feulgen's technique using Schiff reagent and squashed in a drop of $2 \%$ acetic orcein. Slides were made permanent using Bowen's method (1956) and mounted in Euparal.

\section{BASIC CHROMOSOME NUMBERS}

In the Sapindaceae, chromosome numbers for 42 gen- era belonging to 13 tribes and approximately 138 species have been reported, including the new counts presented in this paper, leaving only one tribe karyologically undefined.

Table II shows that there is a considerable variation in chromosome numbers within the family as a whole. Paullinieae showed an almost complete aneuploidy series, from $\mathrm{x}=7$ to $\mathrm{x}=14$, only $\mathrm{x}=8$ and $\mathrm{x}=13$ being absent. The discovery of $2 \mathrm{n}=14$ in Cardiospermum integerrimum Radlk. (Ferrucci, 1989) was the first record of $x=7$ in New World Sapindales, while the count of $2 \mathrm{n}=18$ in $C$. anomalum (Table I) establishes a new basic chromosome number, $\mathrm{x}=9$, for the family. In Sapindales, the families Bretschneideraceae and Akaniaceae included in the past in Sapindaceae have $\mathrm{x}=9$.

The basic chromosome numbers $\mathrm{x}=7,9$ and 10 are exclusive to New World species, while $\mathrm{x}=13$ is only known for two closely allied tribes of the Old World. Among the 42 genera cytologically explored, only 7 exhibit more than two basic numbers.

According to available data, $\mathrm{x}=15, \mathrm{x}=16$ and $\mathrm{x}=14$ occur with the greatest frequency, while other basic numbers are less frequent (Table II). In Paullinieae, the most advanced tribe of the family, the higher basic chromosome numbers $\mathrm{x}=15$ and $\mathrm{x}=16$ are absent. Considering that $\mathrm{x}=$ 7 would be the primitive base number for the family (Ferrucci, 1989), the other chromosome numbers would be derived by polyploidy and aneuploidy.

\section{POLYPLOIDY}

One-third to one-half of the angiosperms are estimated to be polyploid which has, thus, played an important role in the evolution of higher plants (Stebbins, 1971; Greilhuber and Ehrendorfer, 1988), but polyploid frequency in Sapindaceae is scarce, with only three genera from different tribes exhibiting polyploid species, all American species with distinct life forms, such as climbers, shrubs and trees. In this context Urvillea Kunth (Paullinieae) possesses two basic numbers, $x=11$ and $x=12$, while among the four species studied with $\mathrm{x}=11$ three ploidy levels are present, $2 n=2 x=22,2 n=4 x=44$ and $2 n=8 x=86$. The widespread species $U$. ulmacea is a unique species with two known cytotypes $2 \mathrm{n}=2 \mathrm{x}=22$ as well as $2 \mathrm{n}=8 \mathrm{x}=86$ in which polyploidy has been followed by reductional aneuploidy (Nogueira et al., 1995). 
Table I - Chromosome numbers of some South American Sapindaceae,

Paullinieae. ${ }^{*}$ New species counts, ${ }^{* *}$ participation of the author in material collection.

\begin{tabular}{|c|c|c|c|}
\hline Taxon & $2 n$ & Figure & Locality and collectors \\
\hline Cardiospermum anomalum Cambess. & $18^{*}$ & $1 \mathrm{~A}$ & Brasil, Minas Gerais, Hatschbach et al., 64784 \\
\hline C. corindum $\mathrm{L}$. & 22 & $1 \mathrm{~B}$ & Brasil, Bahia, Hatschbach et al., 65042 \\
\hline C. grandiflorum Sw. & 20 & $1 \mathrm{C}$ & Brasil, Bahia, Ferrucci et al., 1021 \\
\hline Paullinia coriacea Casar. & $24 *$ & $1 \mathrm{D}$ & Brasil, Rio de Janeiro, Somner et al., 929 \\
\hline P. weinmanniaefolia Mart. & 24 & $1 \mathrm{E}$ & Brasil, Rio de Janeiro, Ferrucci et al., 938 \\
\hline Serjania acutidentata Radlk. & $24 *$ & $1 \mathrm{~F}$ & Brasil, Bahia, Correntina, Ferrucci et al., 997 \\
\hline S. cissoides Radlk. & 24 & $1 \mathrm{G}$ & Paraguay, Amambay, Schinini et al., 33441 \\
\hline S. communis Cambess. & 24 & $1 \mathrm{H}$ & Brasil, Rio de Janeiro, Ferrucci et al., 955 \\
\hline S. confertiflora Radlk. & 24 & & Brasil, Bahia, Jardim, 951 \\
\hline S. grammatophora Radlk. & $24 *$ & $1 \mathrm{I}$ & Brasil, Bahia, Ferrucci et al., 985 \\
\hline S. lethalis St. Hil. & $24 *$ & $1 \mathrm{~J}$ & Brasil, Mato Grosso do Sul, Pott et al., 3261 \\
\hline S. obtusidentata Radlk. & $24 *$ & & Brasil, Minas Gerais, Lombardi, 2037 \\
\hline S. pernambucensis Radlk. & $24 *$ & $1 \mathrm{~K}$ & Brasil, Bahia, Arbo et al., 7205** \\
\hline S. purpurascens Radlk. & $24^{*}$ & $1 \mathrm{~L}$ & Brasil, Minas Gerais, Carvalho et al., 6580** \\
\hline S. salzmanniana Schltdl. & $24 *$ & & Brasil, Pernambuco, Ferrucci et al., 1135 \\
\hline S. subimpunctata Radlk. & 24 & & Brasil, Bahia, Ferrucci et al., 1031 \\
\hline S. suborbicularis Radlk. & $24^{*}$ & $1 \mathrm{M}$ & Brasil, Minas Gerais, Carvalho et al., 6518** \\
\hline \multirow[t]{2}{*}{ Urvillea ulmacea Kunth } & 22 & & Brasil, Bahia, Ferrucci et al., 971 \\
\hline & 22 & $1 \mathrm{~N}$ & Brasil, Mato Grosso do Sul, Pott et al., 7781 \\
\hline U. chacoënsis Hunz. & 22 & 10 & Argentina, Catamarca, S. Toledo et al., 12792 \\
\hline
\end{tabular}

Table II - Distribution of basic chromosome numbers of 42 studied genera in 13 tribes of Sapindaceae.

\begin{tabular}{|c|c|c|c|c|c|c|c|c|c|}
\hline Tribes Basic numbers & $x=7$ & $x=9$ & $x=10$ & $x=11$ & $x=12$ & $x=13$ & $x=14$ & $x=15$ & $x=16$ \\
\hline Paullinieae & 1 & 1 & 1 & 2 & 4 & & 2 & & \\
\hline Thouinieae & & & & & & & 1 & 1 & \\
\hline Sapindeae & & & & & & & 4 & 3 & \\
\hline Aphanieae & & & & & & 1 & 1 & & \\
\hline Lepisantheae & & & & & & 1 & & & 2 \\
\hline Melicocceae & & & & & & & & & 1 \\
\hline Schleichereae & & & & & & & & 1 & 1 \\
\hline Nephelieae & & & & & & & & 5 & 2 \\
\hline Cupanieae & & & & & & & 1 & 1 & 4 \\
\hline Koelreuterieae & & & & & & & & 1 & 1 \\
\hline Cossignieae & & & 1 & & & & & & \\
\hline Dodonaeeae & & & & & & & 1 & & \\
\hline Harpullieae & & & & & 1 & & 1 & 3 & 2 \\
\hline Percentage & 2.4 & 2.4 & 4.6 & 4.6 & 14 & 4.6 & 24 & 35 & 30 \\
\hline
\end{tabular}

The largest and most cosmopolitan genus Allophylus L. (Thouinieae) shows two ploidy levels, with four species possessing $2 \mathrm{n}=2 \mathrm{x}=28$ while A. guaraniticus (A.St.-Hil.) Radlk. has $2 \mathrm{n}=4 \mathrm{x}=56$ (Ferrucci and Solís Neffa, 1997).

Melicoccus P. Browne (Melicocceae) with its two cytologically studied species has two ploidy levels, $2 \mathrm{n}=$ $2 x=32$ as well as $2 n=6 x=96$, which represents the highest chromosome number of the Sapindaceae (Ferrucci and Solís Neffa, 1997).

Although there is relatively little information on the cytology of the family as a whole, the rareness of polyploids is obvious, indicating that other mechanism of speciation plays the main role.

\section{KARYOTYPES AND SYSTEMATICS IN PAULLINIEAE}

The Paullinieae with 7 genera and about 430 species include a quarter of the species of the family, the tribe presenting an almost exclusively neotropical distribution. In Radlkofer's (1931-1934) system there are two subtribes, the Thinouiinae with only one genus, Thinouia Triana \& Planch., and the Paulliniinae with Lophostigma Radlk., Serjania Mill., Houssayanthus Hunz., Paullinia L., Cardiospermum L. and Urvillea. Chromosome numbers have been determined in 58 species distributed amongst the 7 genera of Paullinieae and the karyotypes of 32 species have been described, and, from a cytological point of view, it is the best explored tribe.

The genus Thinouia is considered the most primitive genus in the tribe, and although it has only 9 species karyotype analysis and chromosome number $(2 n=28)$ are only known for T. mucronata Radlk. (Ferrucci and Solís Neffa, 1997; Solís Neffa and Ferrucci, 1998), with karyotype characteristics confirming its basal position in the 
tribe. When compared to other genera of Paullinieae, $T$. mucronata is characterized by small chromosomes with an average chromosome length of $1.47 \mu \mathrm{m}$ as well as by a symmetric karyotype due to the predominance of m-type chromosomes, agreeing well with macromorphological evidence and pollen type. On the basis of cladistic analysis Acevedo-Rodríguez (1993) proposed to place Thinouia in the tribe Cupanieae, but current knowledge supports its position in Paullinieae.

Lophostigma comprises only two species, native to Ecuador, Peru and Bolivia. Karyological information is confined to the chromosome number, $2 \mathrm{n}=28$ of $L$. plumosum Radlk. (Ferrucci and Solís Neffa, 1997). Characters such as climbing habit, stipules and lightly zygomorphic flowers are essential for placing Lophostigma in the subtribe, and the calyx with five free sepals and the semiannular disc suggest a basal position in the Paulliniinae, the chromosome number supporting this hypothesis (Ferrucci and Anzótegui, 1993). Distinctive pollen, unique within Sapindaceae (AcevedoRodríguez, 1993; Ferrucci and Anzótegui, 1993), and the chromosome number are the characters that distinguish Lophostigma from Serjania, its most closely allied genus.

Serjania Mill. with about 231 species is the largest genus of Paullinieae. Chromosome studies include the chromosome counts of 35 species belonging to eleven of the twelve sections of the genus, all with $2 n=24$ (Guervin, 1961; Fernández Casas and Fernández Piqueras, 1981; Ferrucci, 1981, 1985; Sarkar et al., 1982; Maglio et al., 1984; Hemmer and Morawetz, 1990; Acevedo-Rodríguez, 1993; Nogueira et al., 1995; Ferrucci and Solís Neffa, 1997; Solís Neffa and Ferrucci, 1997 and this paper), while new counts for $S$. acutidentata (Figure $1 \mathrm{~F}$ ), S. grammatophora (Figure 1I), S. lethalis (Figure 1J), S. obtusidentata, S. pernambucensis (Figure 1K), S. purpurascens (Figure 1L), S. salzmanniana and S. suborbicularis (Figure $1 \mathrm{M}$ ), all with $2 \mathrm{n}=24$, confirm the consistency of this chromosome number.

The karyotypes of 21 species of Serjania have been studied, in five of which two populations were analyzed (Hemmer and Morawetz, 1990; Nogueira et al., 1995; Solís Neffa and Ferrucci, 1997; Lombello and Forni-Martins, 1998), with the karyotypes showing a moderate degree of asymmetry and gradual differences in chromosome size. Although the predominance of m-type and smtype chromosomes has been noted, st-type and t-type chromosomes are also generally present. Satellite nucleic acid is difficult to detect, although some species have 1 to 3 chromosome pairs with microsatellite nucleic acid attached to the short and long arms of m-type and t-type chromosomes, while $S$. hebecarpa Benth. is the only species in which macrosatellite nucleic acid has been detected associated with one chromosome pair. The size of Serjania chromosomes varies from $0.97 \mu \mathrm{m}$ in $S$. gracilis Radlk. to $4.7 \mu \mathrm{m}$ in $S$. meridionalis Cambess. In the species analyzed there was significant interspecific and intraspecific variation in chromosome length and karyotype formulae.
Within the tribe, Serjania shows morphological affinities to both Lophostigma and Houssayanthus, but differs from Lophostigma in the characters mentioned above and from Houssayanthus only by fruit morphology.

Houssayanthus with only 3 species is distributed from Venezuela to northeastern Argentina, with chromosome numbers being known for 2 species, $H$. incanus (Radlk.) Ferrucci and H. monogynus (Schltdl.) Ferrucci, both with $2 \mathrm{n}=24$ (Ferrucci, 1981). The karyotype of $H$. incanus has been studied and is characterized by a moderate degree of asymmetry due to its high number of smtype chromosomes; one pair of st-type chromosomes bears a microsatellite in the short arm (Solís Neffa and Ferrucci, 1998). The mean chromosome length as well as the degree of asymmetry is similar to the Serjania species studied, which agrees with the close relationship between Houssayanthus and Serjania in which only fruit characteristics differentiate between genera.

Paullinia with about 150 species is mostly neotropical, with chromosome counts having been reported for seven species, including a new count for $P$. coriacea, the cytologically characterized species belonging to four of the 13 sections of the genus, all with $2 n=24$ (Mangenot and Mangenot, 1958; Semple, 1974; Ferrucci, 1981; Guerra, 1986; Ferrucci and Solís Neffa, 1997 and this paper). The karyotypes of three species have been studied in detail, the analysis showing a moderate degree of asymmetry, with $P$. racemosa Wawra having the smallest degree of asymmetry with a predominance of m-type chromosomes, while P. meliaefolia Juss. has the highest degree of asymmetry due to its high number of sm- and st-type chromosomes, and bears a microsatellite on its pair of t-type chromosomes (Solís Neffa and Ferrucci, 1998). In the tribe, Paullinia is recognized by its capsular fruit, arillated seeds and pollen type.

Cardiospermum is a genus of herbs, vines or suffrutescent herbs and has 14 species native to the Americas, three of them being also present in the paleotropics. Chromosome counts are now known for six species representing the three sections of the genus, $C$. integerrimum Radlk., 2n = 14 (Ferrucci, 1989); C. grandiflorum, 2n = 20 (Ferrucci, 1981, 1989) and 2n = 22 (Dalgaard, 1986; Paiva and Leitão, 1989); C. halicacabum L., 2n = 22 (Sugiura, 1931); C. halicacabum L. var. microcarpum (Kunth) Blume, 2n=22 (Ferrucci, 1981), C. corindum L., $2 \mathrm{n}=22$ (Diers, 1961); C. pterocarpum Radlk., $2 \mathrm{n}=22$ (Ferrucci, 1989) and $C$. anomalum, $2 \mathrm{n}=18$ (this paper).

The genus presents four basic numbers, $x=7, x=10$ and $\mathrm{x}=11$ belong to the species of the Ceratadenia section, $\mathrm{x}=11$ to species of the Cardiospermum section and $\mathrm{x}$ $=9$ to species of the Carphospermum section. The presence of different basic chromosome numbers supports the macromorphological characters that identify the sections. The karyotype of 4 species has been studied in detail (Ferrucci, 1989; Hemmer and Morawetz, 1990), with $C$. halicacabum showing small chromosomes ranging from 0.6 

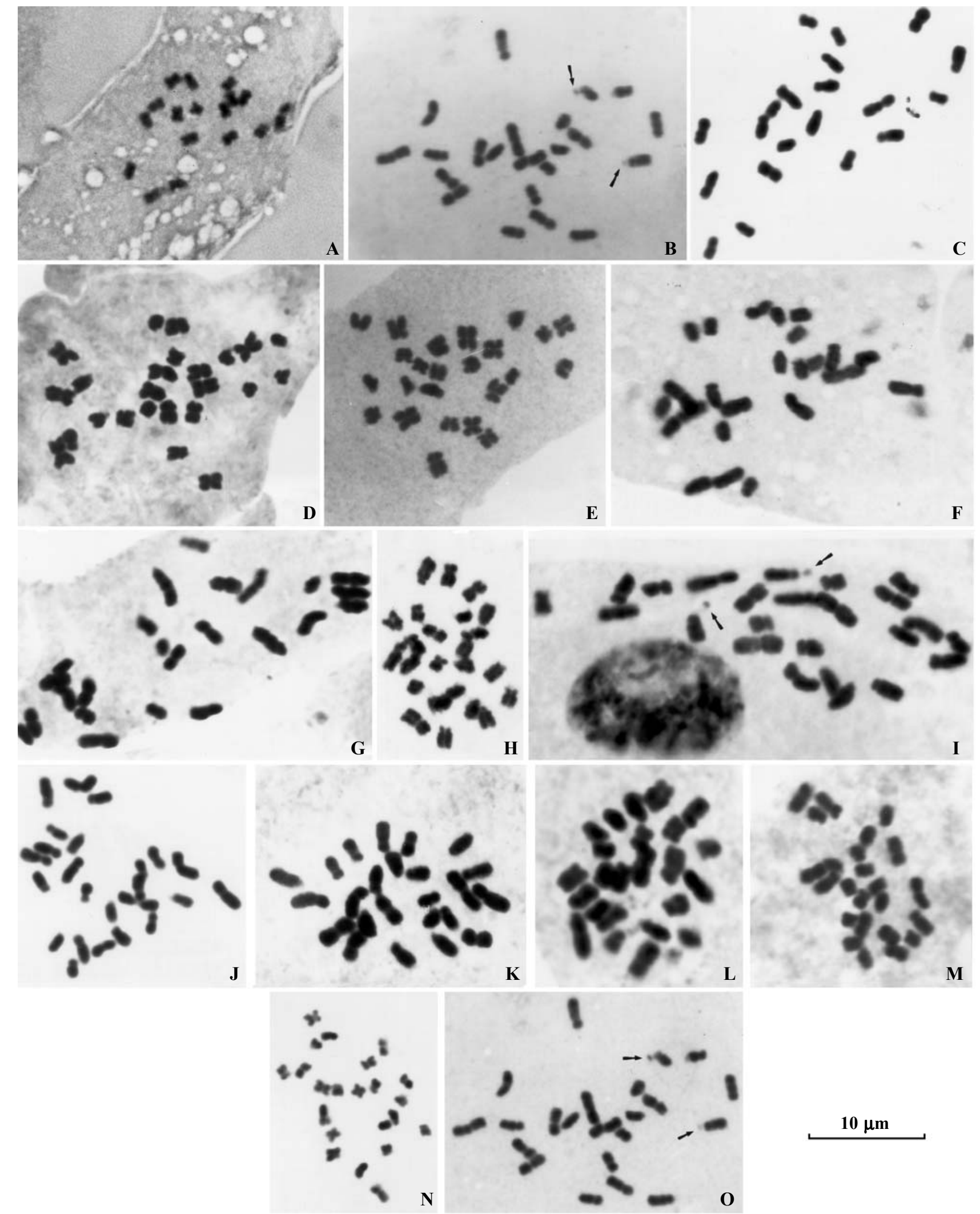

$10 \mu \mathrm{m}$

Figure 1 - Somatic chromosomes of Sapindaceae, Paullinieae. A: Cardiospermum anomalum, $2 \mathrm{n}=18$. B: C. corindum, $2 \mathrm{n}=22$. C: . grandiflorum, $2 \mathrm{n}=20$. D: Paullinia coriacea, $2 \mathrm{n}=24$. E: P. weinmanniaefolia, $2 \mathrm{n}=24$. F: Serjania acutidentata, $2 \mathrm{n}=24$. G: $S$. cissoides, $2 \mathrm{n}=24$. H: $S$. communis, $2 \mathrm{n}=24$. I: $S$. grammatophora, $2 \mathrm{n}=24$. J: S. lethalis, $2 \mathrm{n}=24$. K: S. pernambucensis, $2 \mathrm{n}=24$. L: S. purpurascens, $2 \mathrm{n}=24$. M: S. suborbicularis, $2 \mathrm{n}=24$. N: Urvillea ulmacea, $2 \mathrm{n}=22$. O: $U$. chacoënsis, $2 \mathrm{n}=22$. Arrows indicate microsatellites. 
to $1.5 \mu \mathrm{m}$, while in $C$. integerrimum the chromosome length ranges from 2.57 to $4.36 \mu \mathrm{m}$. The analysis of asymmetry level showed that C. pterocarpum has a symmetric karyotype, mainly composed of m-type and several sm-type chromosomes, while $C$. integerrimum has the most asymmetric karyotype with one submetacentric, one subtelocentric and one telocentric pair. In two species microsatellite nucleic acid was observed. In the Paullinieae, Cardiospermum is differenciated from Urvillea by flower and fruit characters.

Urvillea has 17 species distributed from the southern United States to central Argentina. Only 5 species have been cytologically studied, $U$. uniloba Radlk., $2 \mathrm{n}=44, U$. chacoënsis, $2 \mathrm{n}=22$ (Ferrucci, 1981), U. ulmacea, $2 \mathrm{n}=$ 22, 86 (Ferrucci, 1991; Nogueira et al., 1995), U. peruviana Ferrucci, $2 \mathrm{n}=22$ (Ferrucci, 1997a) and U. laevis Radlk., 2n = 24 (Ferrucci, 1997b; Lombello and ForniMartins, 1998). Urvillea possesses two basic chromosome numbers, $\mathrm{x}=11$ in diploids and polyploid species of the section Urvillea, and $\mathrm{x}=12$ in U. laevis which belongs to the Stenelytron section, the other section of the genus. The two basic chromosome numbers provide additional evidence for the distinctness of the two sections of Urvillea. The karyotypes of $U$. ulmacea, $2 \mathrm{n}=86$, and $U$. laevis have been analyzed (Nogueira et al., 1995; Ferrucci, 1997b; Lombello and Forni-Martins, 1998). In the $U$. ulmace a analysis showed small chromosomes, ranging from 0.64 to $2.4 \mu \mathrm{m}$, while in $U$. laevis the chromosome size ranged from 2.5 to $6.57 \mu \mathrm{m}$, both species having symmetric karyotypes with a predominance of $m$-type chromosomes. In U. laevis one pair of sm-type chromosomes bears a microsatellite in the short arm.

\section{CONCLUSIONS}

The genera of the tribe Paullinieae appear to exhibit rather different chromosome patterns. Thinouia and Lophostigma share the chromosome number $2 \mathrm{n}=28$, as well as the small size of the chromosomes, data which are in accordance with the basal position of both genera in the tribe.

The morphologically similar assemblages of Serjania, Houssayanthus and Paullinia appear to have a constant chromosome number of $2 n=24$. Cytologic data available of Serjania suggest that karyotypic evolution involved structural rearrangements.

Cardiospermum is cytologically characterized by a heterogeneity of chromosome numbers, $2 n=14,18,20$ and 22; these data indicate the important role of aneuploidy in karyotypic evolution. Urvillea, a close relative of Cardiospermum, has chromosome numbers of $2 n=22,24,44$ and 86 , and appears to have polyploidy and aneuploidy related to evolutionary changes.

Paullinieae shows variation in chromosome numbers taxonomically useful at the generic level, and also, in certain genera (such as Cardiospermum and Urvillea), at the infrageneric level.
The primitive basic number for Sapindaceae is $\mathrm{x}=7$, from which the widespread $\mathrm{x}=14$ has been derived, while $\mathrm{x}$ $=9,10,11,12,13,15$ and 16 have been derived via polyploidy and aneuploidy.

\section{ACKNOWLEDGMENTS}

The author wishes to thank Eng. Agr. A. Fernández, Lic. V.G. Solís Neffa and MSc. J.G. Seijo for comments on the manuscript. This work was carried out with the financial support of CONICET, SGCyT-UNNE and the National Geographic Society (Grant No. 5343-94).

\section{REFERENCES}

Acevedo-Rodriguez, P. (1993). Systematics of Serjania (Sapindaceae). Part I: A revision of Serjania Sect. Platycoccus. Mem. New York Bot. Gard. 67: 1-93.

Bowen, C.C. (1956). Freezing by liquid carbon dioxide in making slides permanent. Stain Technol. 31: 87-90.

Dalgaard, V. (1986). Chromosome numbers in flowering plants from Madeira. Willdenowia 16: 221-240.

Diers, L. (1961). Der Anteil an Polyploiden in den Vegetationsgürteln der Westkordillere Perus. Z. Bot. 49: 437-488.

Eichhorn, A. and Franquet, R. (1936). Numération chromosomique et évolution nucléaire chez le Koelreuteria paniculata. Compt. Rend. Hebd. Séances Acad. Sci. 202: 1609-1611.

Fernández Casas, J. and Fernández Piqueras, J. (1981). Estudio cariológico de algunas plantas bolivianas. An. Jard. Bot. Madr. 38: 149-152.

Ferrucci, M.S. (1981). Recuentos cromosómicos en Sapindáceas. Bonplandia 5: 73-81.

Ferrucci, M.S. (1985). Recuentos cromosómicos en Allophylus y Serjania (Sapindaceae). Bol. Soc. Argent. Bot. 24: 200-202.

Ferrucci, M.S. (1989). Cromosomas en Cardiospermum y Diplokeleba (Sapindaceae), significado taxonómico y evolutivo. Bonplandia 6: 151164.

Ferrucci, M.S. (1991). Contribuciones citotaxonómicas en Thouinieae y Paullinieae (Sapindaceae). Resúmenes del XXII Congreso Argentino de Genética, San Fernando Del Valle de Catamarca, Catamarca, p. 17.

Ferrucci, M.S. (1997a). Urvillea peruviana (Sapindaceae) nueva especie andina. Bonplandia 9: 237-240

Ferrucci, M.S. (1997b). El número cromosómico de Urvillea laevis (Sapindaceae). Bonplandia 9: 305-306.

Ferrucci, M.S. and Anzótegui, L.M. (1993). El polen de Paullinieae (Sapindaceae). Bonplandia 6: 211-243.

Ferrucci, M.S. and Solís Neffa, V.G. (1997). Citotaxonomía de Sapindaceae sudamericanas. Bol. Soc. Argent. Bot. 33: 77-83.

Greilhuber, J. and Ehrendorfer, F. (1988). Karyological approaches to plant taxonomy. ISI Atlas Sci.: Anim. Plant Sci. 1: 289-297.

Guerra, M. dos S. (1986). Citogenética de Angiospermas coletadas em Pernambuco. I. Rev. Bras. Genét. IX: 21-40.

Guervin, C. (1961). Contribution à l' étude cyto-taxonomique des Sapindacées et caryologique des Mélianthacées et des Didiéréacées. Rev. Cytol. Biol. Vég. 23: 49-87.

Hemmer, W. and Morawetz, W. (1990). Karyological differentiation in Sapindaceae with special reference to Serjania and Cardiospermum. Bot. Acta 103: 372-383.

Lombello, A.R. and Forni-Martins, E.R. (1998). Chromosomal studies and evolution in Sapindaceae. Caryologia 51: 81-93.

Maglio, C.A.F.P., Forni-Martins, E.R. and Da Cruz, N.D. (1984). In: Löve, A (ed.), Chromosome number reports LXXXIV. Taxon 33: 536

Mangenot, S. and Mangenot, G. (1958). Deuxième liste de nombres chromosomiques nouveaux chez diverses Dicotylédones et Monocotylédones d'Afrique occidentale. Bull. Jard. Bot. État 28: 315-329.

Nogueira Zampieri, C., Ruas, P.M., Ruas, C.F. and Ferrucci, M.S. (1995). Karyotypic study of some species of Serjania and Urvillea (Sapindaceae; Tribe Paullinieae). Am. J. Bot. 82: 646-654. 
Paiva, J. and Leitão, M.T. (1989). Números cromossómicos para alguns taxa da Africa Tropical- II. Bol. Soc. Broteriana, Sér. 2 62: 117-130.

Radlkofer, L. (1931-1934). Sapindaceae, in Engler, Pflanzenr. 98 (IV. 165): 11539.

Sarkar, A.K., Datta, N., Chatterjee, U. and Hazra, D. (1982). In: Löve, A. (ed.), IOPB Chromosome number reports LXXVI. Taxon 31: 578.

Semple, J.C. (1974). In: Chromosome numbers of phanerogams. 5. Ann. MO Bot. Gard. 61: 902-903.
Solís Neffa, V.G. and Ferrucci, M.S. (1997). Cariotipos de especies sudamericanas de Serjania (Sapindaceae, Paullinieae). Bonplandia 9: 265-276.

Solís Neffa, V.G. and Ferrucci, M.S. (1998). Cariotipos de Sapindaceae sudamericanas. Bol. Soc. Argent. Bot. 33: 185-190.

Stebbins, G.L. (1971). Chromosomal Evolution in Higher Plants. E. Arnold, London.

Sugiura, T. (1931). A list of chromosome numbers in angiospermous plants. Bot. Mag. Tokyo 45: 353-355. 